\title{
The Effect of Seaweed Extracts on Chemical Composition of Tomato Plant (Solanum lycopersicum)
}

\author{
Mohamed A. El-Sheikh ${ }^{1}$, Samia N. Sleim ${ }^{2}$ and Hamza S. Abou-Elnasr ${ }^{2}$
}

\begin{abstract}
Seaweed extracts usually used in agriculture and horticulture as nutrient supplements, biostimulants, or biofertilizers to improve plant growth and yield. In this study, to explain these effects. GC-MS was used to measure the change in chemical composition of tomato plant that treated with liquid seaweed extracts (LSWE). The effect of LSWE isolated from Ulva lactuca (green algae) and Grateloupia filicina (red algae), on the chemical composition of tomato (Solanum lycopersicum) that ground under greenhouse condition. Were assessed LSWE was sprayed at concentration $(1.5 \%)$ on tomato seedlings seven times (one a week) at the end of seven weeks tomato leaves were collected from each treatment then extracted and subjected to GC-MS analysis. Our results indicate that seedlings treated with LSWE increased the percentage of terpenes in plant leaf extract compared to untreated plants that contained $(\mathbf{1 7 . 1 5 \%})$, while in plants treated with Ulva lactuca and Grateloupia filicina extract it was (35.52\%) and $(35.87 \%)$ respectively. The terpenes content monoterpenes and sesquiterpenes. No pronounced differences were estimated in the aliphatic alcohols content between the treated and untreated plants. Moreover, treatment with Ulva lactuca extract was shown to have an effect in increasing the level of fatty acids $18 \%$ in tomato plant leaves, while there was no effect of treatment with Grateloupia filicina extract, (11\%) compared with untreated plants $(12 \%)$.
\end{abstract}

Key words: Seaweed, Chemical composition, Green algae, Red algae, Tomato.

\section{INTRODUCTION}

Seaweeds are rich in fiber, several minerals, including iodine, polyunsaturated fatty acids (PUFA), proteins, essential amino acids, polysaccharides, and other nutrients. They also contain various types of metabolites such as sesquiterpenes, phlorotannins, bromoditerpenes, halogenated furanones, lectins, and other compounds, which are released by the algae to protect them against various adverse conditions they face (El Arroussi 2019). Seaweeds, therefore, are promising source of diverse biological activities (Venugopal 2019). Seaweed has been used to improve plant growth and yield worldwide. Modern agriculture seeks new biotechnologies that would allow the use of chemical inputs to be reduced without adversely affecting crop yield or the income of farmers. In recent years, for example, the use of natural seaweed products as fertilizer has Permission for partial replacement of traditional synthetic fertilizer (Dhargalkar and Pereira 2005; Hong et al. 2007; Khan et al. 2009; Zodape et al.2010). These extracts are sold as biostimulants liquids because existence of a broad spectrum of plant growth-promoting substances such as auxins, cytokinins, and betaines has been seen by chemical analysis of seaweeds and their products. (Khan et al. 2009). Such substances can affect the development of the shoot and root system (Durand et al. 2003; Stirk et al. 2004). The use of seaweed extracts has been reported to have several beneficial effects. good responses Which include Enhanced germination, root improved, quality of leaves, vigor of plants, and pathogens resistance. The resistance of plants against pathogens is induced by the application of agents called elicitors and can contribute to disease prevention or decreased severity. The strength of elicitor extracted from the seaweed to elicit induced resistance in tomatoes were reported (Khan et al. 2009; Layth et al. 2015). In terms of human consumption, tomatoes are among the most valuable vegetable crops in the world., and They are the most popular garden vegetables as well. However, the intense application of chemical fertilizers and pesticides that affect soil ecology and agricultural systems is one of the key problems facing tomato production. (Villarreal-Sánchez et al. 2003). The aim of this study is to examine the effect of liquid seaweed extracts on the change in chemical composition of tomato plants.

\section{MATERIAL AND METHODS}

Chemicals: All chemicals and solvents were purchased from Merck, Germany.

Algae sampling and extraction: Algal materials were collected from the eastern port of Alexandria, Mediterranean Sea, during April 2019. The collected algal samples were stored in plastic bags and transported to the laboratory in ice box. The samples were initially washed thoroughly with sea water to remove sand and any adhering substance and then washed thoroughly with fresh water to remove salts. The algal species were identified based on the schemes reported in the literature (Bold, 1978; Aleem, 1993 and Coppejans et al., 2009). Sample were oven-dried for 72 
$\mathrm{h}$ at $60^{\circ} \mathrm{C}$, and then ground in an electric mill. This milled material $100 \mathrm{~g}$ was added to $1 \mathrm{~L}$ of distilled water with constant stirring for $15 \mathrm{~min}$ followed by sonication in water bath sonicator for $2 \mathrm{~h}$ at $40^{\circ} \mathrm{C}$. The hot extract was filtered through a Whatman No. 40 filter paper and stored. The liquid seaweed extract (LSWE) stoked at $4^{\circ} \mathrm{C}$ in the lab Phycology, Botany and Microbiology Department, national institute of oceanography and fishers (NIOF). Until use as foliar application spray.

Greenhouse growth: Tomato plants were grown in a growth chamber under controlled condition 16 hours of light at $25^{\circ} \mathrm{C}$ and 8 hours of darkness at $18^{\circ} \mathrm{C}$ in sterilized soil peatmoss. One hundred and fifty 15 days old plants were selected and randomly allocated to various treatment groups and transplanted into pots containing a sand and peatmoss $(2: 1 \mathrm{w} / \mathrm{w})$ soil mix. Tomato plants were fertilized after one week of transplanting and treated with $50 \mathrm{~mL}$ of 20:20:20 (N-P$\mathrm{K})$ soil drench solution. Irrigation was done with water (50 $\mathrm{mL}$ every three days), Potted plants were grown in a greenhouse at $25 \pm 2^{\circ} \mathrm{C}$ and $85 \%$ relative humidity. Plants sprayed with $50 \mathrm{ml}$ of (LSWE 1.5\%) and water for untreated for each treatment every week for 7 weeks. The design and treatment for the experiment were similar to those reported by Crouch and van Staden (1992). The experiment was designed into three different treatments .Each treatment is Five replicates each one consisting of ten plants. The control was the first treatment which plants were grown without LSWE. The other two treatment treated with the two type of seaweed species used to produce the LSWE.

Extraction methods: After 7 weeks spray tomato plant leaves from each treatment were extracted. Harvest the leaves $(1.0 \mathrm{~g})$ from tomato immediately freeze at $-80{ }^{\circ} \mathrm{C}$ and Frozen tissues dried using Lyophilizer then tissue Transferred in a glass vial with cap and 10 $\mathrm{ml}$ of methanol was added and $1 \mathrm{~g}$ sodium sulfate anhydrous then sonication was done using water bath sonicator at $37{ }^{\circ} \mathrm{C}$ for $2 \mathrm{~h}$. Result and extract wase filtered through a syringe filter $0.2 \mu \mathrm{m}$, evaporated under vacuum at $45^{\circ} \mathrm{C}$. Organic extracts results were dissolved in methanol and used for injection in GC-MS.

Chemical analysis: GC/MS analyses were conducted in Central Lab of national institute of oceanography and fishers (NIOF). The GC-MS analysis was done using A Thermo Scientific gas chromatograph GC TRACE ULTRA 1300 coupled with an EI Mass spectrometer ISQ 7000 model (Thermo Scientific USA) equipped with Thermo TR-50 MS capillary column $(30 \mathrm{~m}$ in length $\times 250 \mu \mathrm{m}$ in diameter $\times 0.25 \mu \mathrm{m}$ film thickness).
Spectroscopic detection by GC-MS involved an electron ionization system which utilized high energy electrons $(70 \mathrm{eV})$, MS transfer line temperature $300{ }^{\circ} \mathrm{C}$ and ion source temperature $300{ }^{\circ} \mathrm{C}$. Pure helium gas $(99.995 \%)$ was used as the carrier gas with flow rate of $1 \mathrm{~mL} / \mathrm{min}$. The initial temperature was set at $60^{\circ} \mathrm{C}$ for 2 min, then increased to $100{ }^{\circ} \mathrm{C}$ at a rate of $10{ }^{\circ} \mathrm{C} / \mathrm{min}$ kept for $5 \mathrm{~min}$, then with $10{ }^{\circ} \mathrm{C} / \mathrm{min}$ to $150{ }^{\circ} \mathrm{C}$ and kept for $5 \mathrm{~min}$, then with $10^{\circ} \mathrm{C} / \mathrm{min}$ to $200{ }^{\circ} \mathrm{C}$ and kept for 5 min, then with $10{ }^{\circ} \mathrm{C} / \mathrm{min}$ to $250{ }^{\circ} \mathrm{C}$ and kept for 20 min. One microliter of the prepared extracts was injected in a splitless mode. Wiley and Wiley NIST mass spectral data base were used in the identification of the separated peaks.

\section{RESULTS AND DISCUSSION}

The results obtained from analyzing tomato leaf extract using mass GCMS are shown in (Figure 1). The emergence of a variety of compounds and active groups are shown in (Table 1).

The results are expressed in percentage of the methanolic extract of tomato leaves Solanum lycopersicum

The data showed that most important of existence compounds are the terpenes (Figure 2), where 6 compounds of terpenes appeared, 4 compounds belonging to monoterpene. $\alpha$-Terpinene, Phellandrene, Z-Citral and 2-carene and two compounds of sesquiterpenes, Caryophyllene and $\alpha$-Elemene. The results indicated that treatment with LSWE had an effect on terpenes levels in tomato plants $S$. lycopersicum, where the percentage of terpenes results of treatment with LSWE isolated from $U$. lactuca (green algae) was $35.87 \%$, while LSWE made from G. filicina (red algae) was $35.52 \%$, while the untreated plant values were $17.15 \%$. The results showed a pronounced difference were estimated of treatment with LSWE. There was No differences between treatment with LSWE made from red or green algae, as the results obtained proved the presence of terpenes in the extract, and these results are compatible with (Ghada et al. 2017 and María et al. 2017). As has been proven in previous studies, terpenes are considered compounds that have a strong effect on plant pathogens, especially bacteria and fungi, and some of them have an effect on some types of insects and worms. Riju et al. (2019). These results may explain how the algae effect increases the resistance of plants treated with algae, which naturally leads to the good growth of the plant and the plant becomes healthier. 

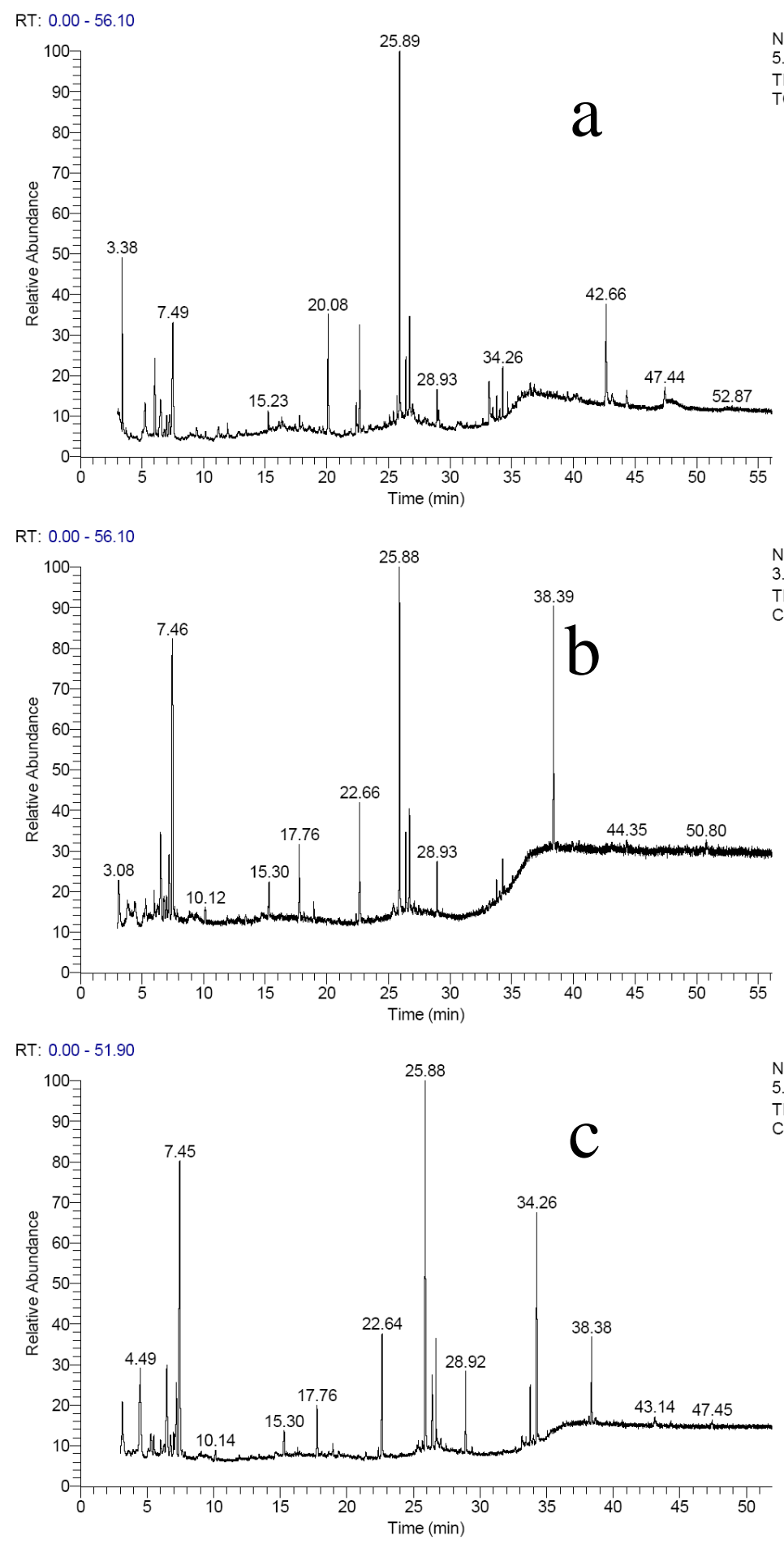

Fig. 1. GCMS analysis of tomato (Solanum lycopersicum) leaf methanolic extract, untreated tomato (a), treated with Ulva lactuca (green algae) extract (b) and treated with Grateloupia filicina (red algae) extract (c) 
Table 1. Main components of tomato leaves extracts in control, Ulva lactuca (green algae) extract and Grateloupia filicina (red algae) extract and identified by GC/MS

\begin{tabular}{|c|c|c|c|c|}
\hline \multirow{2}{*}{$\begin{array}{l}\text { R. } \\
\text { Time }\end{array}$} & \multirow[t]{2}{*}{ Compounds } & Control & $\begin{array}{c}\text { U. lactuca } \\
\text { (green algae) }\end{array}$ & $\begin{array}{l}\text { G. filicina } \\
\text { (red algae) }\end{array}$ \\
\hline & & $\%$ & $\%$ & $\%$ \\
\hline 3.09 & Tetraacetyl-d-xylonic nitriled- & N.D. & 3.29 & N.D. \\
\hline 315 & Cyclododecanone, thiosemicarbazone & N.D. & N.D. & 3.28 \\
\hline 3.19 & 2-methyl-1,3-Butanediol, & 0.76 & N.D. & N.D. \\
\hline 3.81 & 2H-Pyran,tetrahydro-2-(2,5-undecadiynyloxy)- & N.D. & 2.06 & N.D. \\
\hline 4.40 & 5,7-Dodecadiyn-1,12-diol & N.D. & 1.41 & N.D. \\
\hline 4.49 & 3-Hexenal & N.D. & 0.67 & 6.52 \\
\hline 5.25 & n-Decane & 2.98 & 1.35 & 1.28 \\
\hline 5.51 & Hexadecane, 1,1-bis(dodecyloxy)- & N.D. & N.D. & 1.11 \\
\hline 6.04 & 2-hydroxy-2-methyl-Propanoic acid, & 3.70 & 1.15 & 0.71 \\
\hline 6.50 & $\alpha$-TERPINEN) & 3.92 & 5.94 & 6.26 \\
\hline 6.77 & 8,11-Octadecadiynoic acid, methyl ester & N.D. & 1.58 & 1.37 \\
\hline 7.01 & Undecane & 1.54 & 1.16 & 0.90 \\
\hline 7.24 & 2-Carene & 1.80 & 3.96 & 5.18 \\
\hline 7.49 & $\alpha$-Phellandrene & 9.47 & 18.90 & 19.15 \\
\hline 10.16 & 3-hydroxy-2-Dodecanoic acid, & 0.53 & 0.93 & 0.60 \\
\hline 11.20 & 9-Octadecen-12-ynoic acid, methyl ester & 0.97 & N.D. & N.D. \\
\hline 11.94 & $\alpha$-methyl-Benzeneethanamine, & 0.93 & 0.46 & N.D. \\
\hline 15.23 & 2-methyl-1-Hexadecanol, & 1.01 & N.D. & N.D. \\
\hline 15.30 & $\alpha$-Elemene & N.D. & 2.17 & 1.44 \\
\hline 16.32 & 2-Hexadecanol & 0.46 & N.D. & N.D. \\
\hline 17.79 & Caryophyllene & 1.02 & 4.26 & 2.75 \\
\hline 18.94 & 2,5-Octadecadiynoic acid, methyl ester & N.D. & 1.05 & 0.60 \\
\hline 20.09 & $\begin{array}{l}\text { Fumaric acid, ethyl2-(2-methylenecyclopropyl) } \\
\text { propyl ester }\end{array}$ & 7.76 & 0.48 & N.D. \\
\hline 22.38 & $\begin{array}{l}\text { 2H-Indeno[1,2-b] furan-2-one-octahydro- } 8,8 \text { - } \\
\text { dimethyl }\end{array}$ & 1.90 & 0.54 & 0.60 \\
\hline 22.65 & 3,7,11,15-Tetramethyl-2-hexadecen-1-ol & 6.29 & 6.13 & 6.06 \\
\hline 25.07 & 12-Methyl-E, E-2,13-octadecadien-1-ol & 0.48 & N.D. & N.D. \\
\hline 25.39 & 2-Hexadecanol & 0.61 & 0.68 & 0.58 \\
\hline 25.68 & 3,7,11-trimethyl-1-Dodecanol, & 1.08 & 0.29 & 0.36 \\
\hline 25.89 & Phytol & 13.93 & 12.34 & 12.61 \\
\hline 26.41 & 13-Heptadecyn-1-ol & 2.42 & 3.10 & 2.81 \\
\hline 26.69 & 1-Octadecyne & 4.33 & 4.39 & 3.85 \\
\hline 28.93 & Hexadecanoic acid, methyl ester & 2.18 & 2.75 & 3.56 \\
\hline 33.16 & (3,5à)-Cholestan-3-ol, 2-methylene-, & 2.69 & N.D. & 0.63 \\
\hline 33.46 & Ethyl iso-allocholate & 0.67 & N.D. & 0.39 \\
\hline 33.77 & (Z,Z,Z)-8,11,14-Eicosatrienoic acid, & 1.09 & 1.08 & 2.30 \\
\hline 34.03 & (E)-10-Heptadecen-8-ynoic acid, methyl ester, & 0.59 & 0.67 & 0.52 \\
\hline 34.26 & Linolenic acid, methyl ester & 2.11 & 1.59 & 8.40 \\
\hline 34.67 & 9-Hexadecenoic acid & 1.09 & N.D. & N.D. \\
\hline 35.46 & 1-Heptatriacotanol & 0.44 & N.D. & N.D. \\
\hline 43.13 & Z-Citral & 0.94 & 0.64 & 0.74 \\
\hline
\end{tabular}




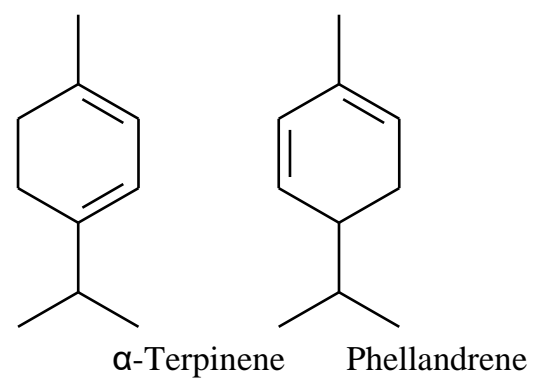

(Z-Citral)<smiles>C=C1CC/C=C(/C)CC[C@H]2C[C@@H]1CC2C</smiles>

Caryophyllene<smiles>CC(C)=CCCC(C)=CC=O</smiles>

Geranial<smiles>CC(C)=CCCC(C)=CC=O</smiles><smiles>C=CC1(C)CCC(=C(C)C)CC1=C(C)C</smiles>

a-Elemene<smiles>CC1=CC2C(C)C2(C)CC1</smiles>

2-carene

Fig. 2. Chemical structure of monoterpenes and sesquiterpenes in tomato (Solanum lycopersicum) leaf methanolic extract

Fatty acids are also among the important groups that are present in the tomato plant, as shown in (Table 1), which has a very important role in biological processes and increase plant resistance to pathogens and unfavorable conditions The results showed that the treatment with algae extract affected the fatty acid content. The effect was greater in the case of treatment with green algae extract, where the percentage of fatty acids was $18 \%$, while the treatment with red algae

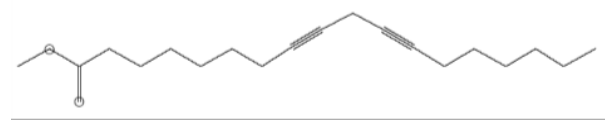

8,11-Octadecadiynoic acid, methyl ester

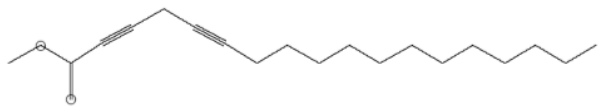

2,5-Octadecadiynoic acid, methyl ester

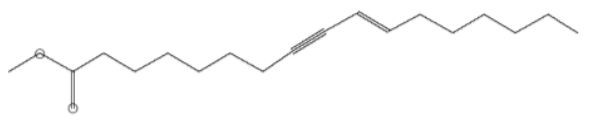

(E)-10-Heptadecen-8-ynoic acid, methyl ester extract was $11 \%$ compared to the non-treatment was $12 \%$. A pronounced differences were estimated in the case of treatment with green algae extract in one site and red algae extract or control in another site. Similar results were obtained by Hansson et al. (2012), they proved the presence of ethyl ester in tomato extract. Tikunov et al. (2005), also, recognized hexadecanoic acid, ethyl ester in tomato plant extract (Lycopersicone sculentum) genotype.
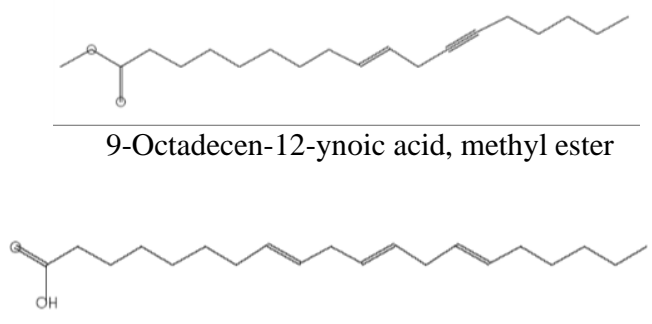

cis-8,11,14-Eicosatrienoic acid,

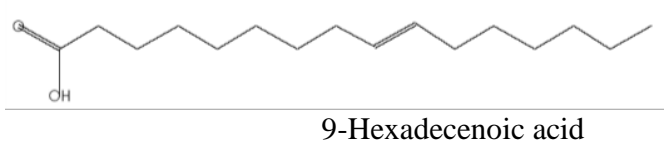

9-Hexadecenoic acid

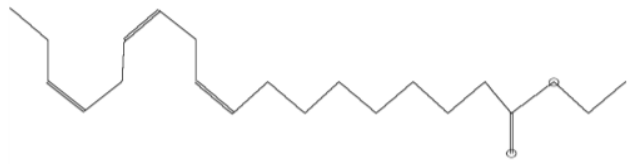

Linolenic acid, methyl ester

Fig. 3. Chemical structure of unsaturated fatty acid (USFA) in tomato (Solanum lycopersicum) leaf methanolic extract 
The unsaturated fatty acids were also considered due to their great importance, as shown in (Figure 3). The results showed that most of the fatty acids are unsaturated fatty acids in the case of treatment with green algae extract, where it was $13.19 \%$. While in the case of treatment with red algae extract, it was similar to the non-treatment where the percentage of unsaturated fatty acids was $5.97 \%$ and $5.85 \%$, respectively, which shows the decrease in saturated fatty acids, unlike in the case of treatment with green algae extract, that showed increase.

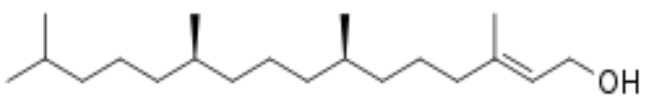

Fig. 4. Phytol

While there were no pronounced differences were estimated in the percentage of aliphatic alcohols as a result of the different treatments. The most important compounds are phytol and 3,7,11,15-Tetramethyl-2hexadecen-1-ol, as shown in (Figure 4), where 13\% and $6 \%$ were present, respectively, as shown in (Table 1). Similar results were obtained by Juliana et al. (2016) they recognized phytol as bioactive compound of tomato extract. Also, Hansson et al. (2012) reported that treatment with green algae (Ulva lactuca) extract led to an increase in the concentration of some biologically important compounds such as Tetraacetyl-d-xylonic nitriled - as in Figure 5. This compound have bioefficiency as stated in the study at Imad et al. (2015). that proved the presence of the compound in the methanolic extract and has efficacy against bacteria and fungi. This finding may ex. Tetraacetyl-d-xylonic nitriled might be an indication of plant tolerant or resistant against microbiological pathogens explain the improvement of the plant's condition and increase its resistance against infection with fungal and bacterial pathogens. Generally of some important compounds such as terpenes, phenols, fatty acids, especially unsaturated and other compounds.

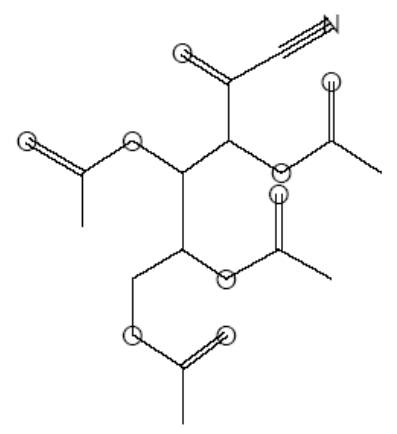

Fig. 5. Tetraacetyl-d-xylonic nitriled

\section{CONCLUSION}

The results show that the treatment with LSWE had a great effect on increasing the levels of very important compounds, especially green algae. Therefore, by looking at the change in the chemical composition as a result of treatment with algae extract explains the improvements that might occur to the plant from that treatment.

\section{REFERENCES}

Aleem, A. A. 1993. The marine algae of Alexandria, Egypt, Univ. Alexandria. $139 \mathrm{pp}$.

Bold, H. C. and M. J. Wynne. 1978. Introduction to the Algae. Structure and Reproduction. Englewood Cliffs. New Jersey, Prentice-Hall, xiv+706 p.

Coppejans, E., F.Leliaert, O.Dargent, R.Gunasekara and O. De Clerck. 2009. Sri Lankan seaweeds methodologies and field guide to the dominant species. Abc Taxa 6 (iviii):265.

Crouch, I. J. and J. van Staden. 1992. Effect of seaweed concentrate on the establishment and yield of greenhouse tomato plants. J Appl Phycol. 4:291-296.

Dhargalkar, V. K. and N.Pereira. 2005. Seaweed: promising plant of the millennium. Sci Cult. 71:60-66.

Durand, N., X. Briand and C. Meyer. 2003. The effect of marine bioactive substances (NPRO) and exogenous cytokinins on nitrate reductase activity in Arabidopsis thaliana. Physiol Plant. 119:489-493.

El Arroussi, H. 2019. "Marine polysaccharides as promising source of biological activities: Extraction and purification technologies, structure and activities". In Enzymatic Technologies for Marine Polysaccharides, Trinicone, A. (Ed.) CRC Press, Boca Raton, Chapter 13.

Ghada, E. A., Manal, E. A. Elshaier, E. M. Amal and E. M. Hala. 2017. Application of tomato leaves extract as pesticide against Aphis gossypii glover (Hemiptera: Aphididae). Int. J. Adv. Res. 5(4):286-290.

Hansson, D., M. J. Morra and S. D. Eigenbrode. 2012. Green peach aphid (Myzus Persicae Suler) (Hemiptera: Aphididae) control using Brassicaceae ethyl ester oil sprays. J. Appl. Entomol. 12: 1-10.

Hong, D. D., H. M. Hien and P. N. Son. 2007. Seaweeds from Vietnam used for functional food, medicine and biofertilizer. J Appl Phycol. 19:817-826.

Imad, H. H., F. H. Lena and Sabreen, A. Kamal. 2015. Analysis of bioactive chemical compounds of Aspergillus niger by using gas chromatography-mass spectrometry and fourier-transform infrared spectroscopy. $J$. of Pharmacognosy and Phytotherapy. 7 (8): 132-163.

Julian, A., S.Mariana, S. Livia and G. Luzia. 2016. Downregulation of tomato phytol Kinase strongly impairs tocopherol biosynthesis and affect prenyllipid metabolism in an organ- specific manner. J. Exp. Bot. 67 (3): 919- 934. 
Khan, W., U. P.Rayirath, S.Subramanian, M. N.Jithesh, P.Rayorath, D. M. Hodges. 2009. Critchley AT, Craigie JS, Norrie Jand Prithiviraj B, Seaweed extracts as biostimulants of plant growth and development. Plant Growth Regul . 28:386-399.

Layth, M., M. N. M.Ansari, P. Grace, J. Mohammad and M. S. Islam. 2015. A review on natural fiber reinforced polymer composite and its applications. International J. of Polymer Science. 243947: 15.

María, P. L. G., L. Purificación, C. Laura, R.Ismael, L. R.José, G.Antonio, C. Vicente and M. B. José. 2017. A nontargeted metabolomics approach unravels the VOCs Associated with the tomato immune response against Pseudomonas syringae. Frontiers in Plant Sci.July. 8:.1188.

Riju, S., A.Kamal, M.Sudarshana and K. Bulbuli. 2019. Combinations of plant essential oil based terpene compounds as larvicidal and adulticidal agent against Aedes aegypti (Diptera: Culicidae). Scientific RepoRts. 9:9471.
Stirk, W. A., G. D.Arthur, A. F.Lourens, O. Novák, M. Strnad. and J. van Staden. 2004. Changes in cytokinin and auxin concentrations in seaweed concentrates when stored at an elevated temperature. J Appl Phycol. 16:31-39.

Tikunov, Y., L.Arjen, A.Harrie, D.Robert and G. Arnaud. 2005. A novel approach for nontargeted data analysis for metabolomics. Large- scale profiling of tomato fruit volatiles. Plant Physiol. 139: 1125-1137.

Villarreal-Sánchez, J. A., A. Ilyina, L. P.Mendez-Jiménez, V.Robledo-Torres, R.Rodríguez-Herrera, B. CanalesLópez and J. Rodríguez-Martínez. 2003. Isolation of microbial groups from a seaweed extract and comparison of their effects on a growth of pepper culture (Capsicum annuum L.). Moscow Univ Chem Bull. 44:92-96.

Venugopal, V. 2019. Sulfated and Non-Sulfated Polysaccharides from Seaweeds and their Uses: An Overview. EC Nutrition. 14.2: 126-141.

Zodape, S. T., S.Mukhopadhyay, K.Eswaran, M. P. Reddy and J.Chikara. 2010. Enhanced yield and nutritional quality in green gram (Phaseolus radiata L.) treated with seaweed (Kappaphycus alvarezii) extract. J Sci Ind Res. 69:468471.

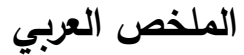 \\ تأثير مستخلصات الطحالب البحرية على التركيب الكيميائي لنبات الطماطر \\ (Solanum lycopersicum) \\ محمد احمد الثيخ، سامية نعيم سليم وحمزة سمير أبوالنصر}

GC-MS باستخدام كروماتوجراف الغاز - مطياف الكتلة حيث أظهرت النتائج ان المعاملة بمستخلص الطحالب ادي لزيادة نسبة التربينات في أوراق النبات حيث كانت نسبة

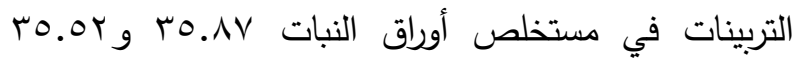

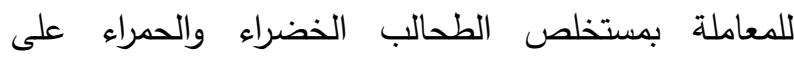

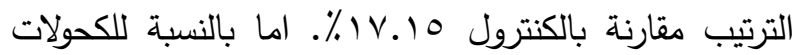
الأليفاتية لم يكون هناك فرق يذكر بين المعاملات المختلفة. بينما أدت المعاملة بمستخلص الطحالب الخضراء لزيادة مستويات الاحماض الدهنية في مستخلص أوراق نبات الطماطم حيث كانت ^1 ٪ بينما الطحالب الحمراء كانت

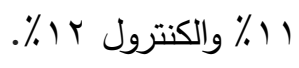

الطحالب البحرية أصبح لها دور هام في مجالات عديدة خاصة في مجال الزراعة حيث تستخدم مستخلصاتها كمخصبات طبيعية للنبات حيث تعمل علي تحسين النمو الخضري والجذري وتحسين مواصفات المنتج ورفع المناعة المستحثة في النبات. في هذه الدراسة تم دراسة تأثير المعاملة بمستخلص نوعين من الطحالب البحرية الطحالب الخضراء Glva lactuca التغير في التركيب الكيماوي في نبات الطماطم تحت ظروف متحكم بها بالصوبة حيث تم معاملة النبات رشاً بمستخلص الطحالب بتركيز 0. 1\% عدد سبع مرات لبادرة الطماطم بمعدل معاملة أسبوعيا لمدة سبع أسابيع. تم جمع أوراق الطماطم للمعاملات والكنترول وتم استخلاصها للتحليل 